\title{
Tütarlapsest sirgub naine Hoiatusjutud tütarlastele populaarses meditsiinikirjanduses
}

\begin{abstract}
Andreas Kalkun
Teesid: Ene Koogi Tütarlapsest sirgub naine (1978, 1979, 1986) on noortele naistele ja tütarlastele suunatud didaktiline raamat, kus kohtuvad folkloor ja meditsiin. Didaktilises tekstis leiduvad õpetlikud narratiivid, mis pärinevad väidetavalt elust, kuid meenutavad oma olemuselt folkloorseid tekste, kandes selgelt ülesannet õpetada noortele naistele selgeks ühiskonnas kehtivad sooideoloogiad ja kehaga seotud tabud. Üleva ja madala didaktilistel eesmärkidel ühendamine ning ladusate narratiivide konstrueerimine kannab kindlat eesmärki mõjutada lugejat. Artiklis iseloomustatakse antud teost, selle kohta oma ajas ning seal leiduvaid narratiive ja poeetikat. Kui asetada raamat folkloristlike tekstide konteksti ja kõrvutada populaarses meditsiinitekstis leiduvaid narratiive rahvaluuležanridega, tekib omamoodi võõristusefekt. Sellise kõrvutamise ja võõristusefekti kaudu võib näha populaarse meditsiiniteksti ja traditsiooniliste jutužanride sarnasust.
\end{abstract}

Märksõnad: didaktiline kirjandus, populaarteaduslik meditsiinikirjandus, puberteet, sooideoloogiad, terviseõpetus Eesti NSVs, tõsielujutud

Meie kodus oli üks riiul, kus hoiti n-ö meditsiinikirjandust: seal olid populaarsed tervishoiuentsüklopeediad, nagu Harri Jänese, Hubert Kahni ja H. Rootsi koostatud Tervise ABC (Tallinn: Valgus 1970), õpetlikud seksuaalelu käsitlused eesotsas soomlaste Martti Paloheimo, Mauri Rouhunkoski ja Mirja Rutaneni teose Avameelselt abielust lühendatud tõlkega (Tallinn: Valgus 1974), hügieeni ja ilu (Sofia Wedrowska 100 minutit ilu heaks (Tallinn: Valgus 1978) ja Helena Vojačkova Liikumine - naise tervise ja ilu pant (Tallinn: Valgus 1967)) ning lastekasvatuse (Benjamin Spocki Teie laps (Tallinn: Valgus 1976)) käsiraamatud, samuti brošüürid noortele emadele. Muu hulgas olid seal ka Heiti Kadastiku Vestlusi noorukitele: Psühhiaatri nõuandeid puberteedieale (Tallinn: Valgus 1966), Ene Koogi Tütarlapsest sirgub naine (Tallinn: Valgus 1978) ning Rudolf Peter, Vacia (= Václav) Šebek ja Josef Hynie Tütarlapsest naiseks (Tallinn: Eesti Riiklik Kirjastus 1962). Koolilapsena lappasin kõiki neid raamatuid suure huviga. Sealt võis leida hirm- 

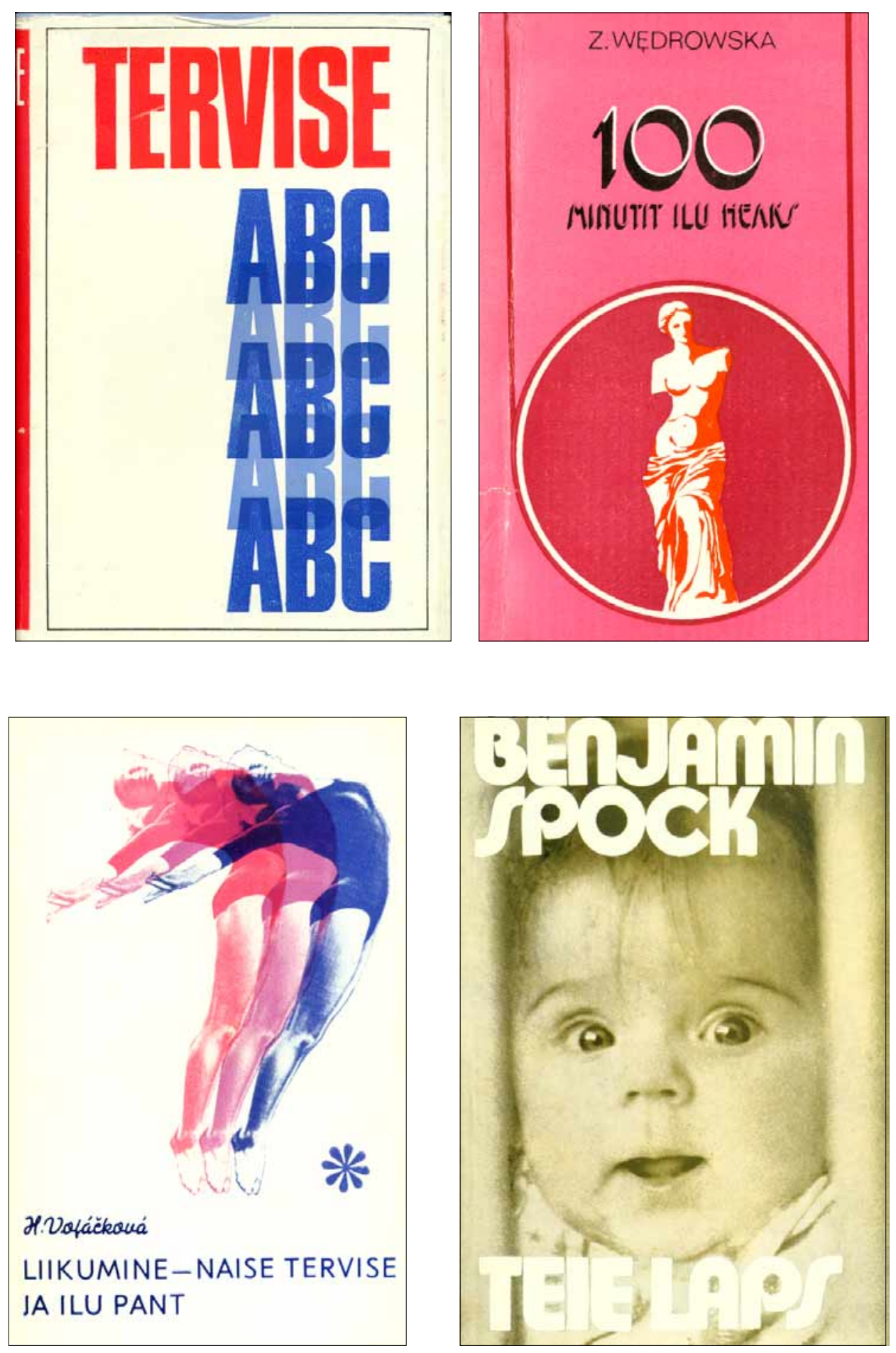
said pilte prepareeritud elunditest, põletushaavadest ning naha- ja suguhaigustest. Lisaks koledatele fotodele ja joonistele võis nendest raamatutest otsimise korral leida ka hirmsaid ja salapäraseid lugusid koledatest haigustest ja rumalatest inimestest, kes oma ignorantsuse või hoolimatusega on põhjustanud endale mitmesuguseid hädasid.

Kuigi minu lapsepõlves seisis enamik neist raamatuist riiulis, ilma et vanemad oleksid neid kasutanud, võib perepärimusele toetudes arvata, et kunagi oli vähemalt mõnda neist tihedamalt loetud. Nimelt on ema mitmeid kordi rääkinud lugu, kuidas ta 1970 . aastate lõpus

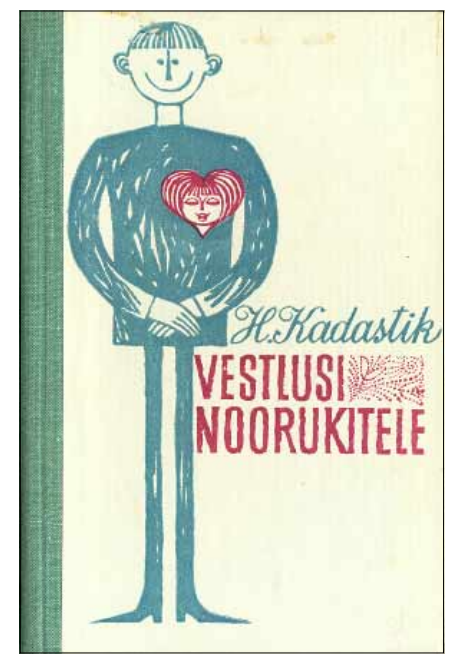
noore lapsevanemana, toetudes populaarsetele imiku toitmist käsitlevatele väljaannetele, oli veendunud, et lapsi tohib toita vaid kindlatel kellaaegadel. Ema olevatki siis mõnda aega üritanud südant kõvaks tehes laste tervise ja heaolu nimel sööta neid vaid teatud kellaaegadel, kuni ämm nutvaid lapsi nägi ja selle ära keelas. Oma kogemustele toetudes käskis ta edaspidi sööta lapsi ka siis, kui need nutavad.

Sellest nutvate imikute ja ema loost kooruvad mõned üldised populaarset meditsiinikirjandust iseloomustavad jooned, mille üle tahaksin järgnevalt mõtiskleda. Didaktilise suunitlusega meditsiini ja hügieeni puudutavates tekstides võib nende kriitilisel lähilugemisel jälgida teatud kindlat tüüpi võimusuhete kehtestamist, teatud seisukohtade esitamist ainuõigetena, rohkelt mõningate tavapäraste käitumismallide ja normaalsete nähtuste patologiseerimist ning teadusliku ehk üleva ja rahvaliku ehk madala diskursuse rõhutatud vastandamist. Teatud tüüpi retooriliste mudelite domineerimine ja õpetlikud näitelood on teemad, mida järgnevalt peamiselt Ene Koogi raamatu Tütarlapsest sirgub naine valgusel vaatlen.

Iseloomustan antud teost, selle kohta oma ajas ning seal leiduvaid narratiive ja poeetikat. Kui asetada antud teos folkloristlike tekstide konteksti ja kõrvutada seal leiduvaid narratiive mõningate rahvaluuležanridega, tekib omamoodi võõristusefekt. Sellise kõrvutamise ja võõristusefekti kaudu võib näha populaarse meditsiiniteksti ja traditsiooniliste jutužanride sarnasust. Nii dekonstrueeritud meditsiinilised narratiivid näitavad oma konstrueeritust ja seotust väga konkreetse ühiskonna ja ideoloogiatega ning tekstid paljastuvad millekski enamaks kui pelgaks tütarlaste hügieeni- ja käitumisõpikuks. 


\section{Tütarlapsest sirgub naine}

Tütarlapsest sirgub naise 1986. aasta trüki annotatsioonis piiritletakse raamatu sihtauditoorium (murdeealised noored neiud, abielunaised ja emad) ning tutvustatakse teost:

Noorukite arstina töötanud ja meditsiinikoolis õpetanud doktor Ene Kook kujutas hästi ette muresid, mis murdeealist tütarlast, küpsevat neiut, vastset abielunaist ja noort ema vaevavad. Selles raamatus jagab ta neile oma teadmisi ja kogemusi. Raamat on abiks ka murdeealiste tütarlaste emadele (Kook 1986: 2).

E. Koogi raamat tütarlastele on ilmunud kolmes trükis aastatel 1978, 1979, 1986 ja ülisuurtes tiraažides (kaks esimest trükki kumbki 50000 ja kolmas trükk 60 000) ning tõenäoliselt on see väga laialt levinud tekst mõjutanud paljusid eesti naisi. Enim on lugejaid kõnetanud tõenäoliselt raamatus toodud õpetlikud ja väga mõjuvad lood õnnetutest ja rumalatest patsientidest.

Raamatu pealkirja esinemust internetist otsides leidsin, et veel kolmandagi aastatuhande hakul meenutavad naised oma internetipäevikuis kõnealust teost või on see arutlusobjektiks Perekooli (http://www.perekool.ee/) foorumites. Tütarlapsest sirgub naises avaldatud lood on tõenäoliselt paljudel naistel igaveseks mällu sööbinud. Antud teosele viitavaid naisi võib lihtsa vaevaga leida muudestki internetifoorumitest. Näiteks 2004. aasta 4. juuni Delfi naistelehe foorumis toob reklaamide mõjul hügieenisidemetest rääkivate laste teema anonüümsele kommentaatorile :)))) meelde lõigu Ene Koogi raamatust ja ta refereerib seda, esitades ka kriitilise arvamuse (kirjaviis siin ja edaspidi muutmata):

Mulle selle halva kogemuse peale meenus millegipärast äkki kunagi loetud raamat "Tütarlapsest sirgub naine", kus kirjeldati üht kohutavalt "piinliku" seika otse elust, kus väike õde noore neiu kapist leitud (PUHTA) sidemega (tol ajal siis iseõmmeldud) külaliste ette tuli. Et oh seda häbi ja piinlikust;))) Mõned elavad vist ikka eelmises sajandis, kus kõik naise keha loomulike protsessidega seonduv on varjamist väärt. Ja appikene, rääkida ei tohi sest ammugi mitte. Ma saaks aru, kui laps mingeid roppusi järgi kordaks... (:)))), 4. juuni 2004, kl 14.34).

Kommentaator, kes kirjutab vastureaktsiooniks artiklile "Eneserahuldamine" Delfi naistelehes enda isiklikest sellealastest kogemustest, tuletab taas meelde E. Koogi raamatut Tütarlapsest sirgub naine:

esimest korda sain vanaemalt kärada kolme aastaselt, kui ta avastas, et ma lõunauinaku asemel mitte just "käed teki peal" asendis pole. 
pubekaeas ei möödunud päevagi, kus ma poleks ennast ise rahuldanud. ise pidasin ennast ebanormaalseks, sest 70-ndate aastate raamatutes (tütarlapsest sirgub naine jne) peeti sellist käelist tegevust perverssuseks. aga ma ei suutnud lõpetada ka, sest nii kaif oli. praegu olen onnelikus abielus, kuid ikka nii paar korda kuus ajan ise asja (liina, 27. aprill 2001, kl 9.37).

Tõenäoliselt esindavad sellised internetist leitud kommentaarid üsna tüüpilist kogemust ja annavad vihjeid, milliseid seoseid ja assotsiatsioone Tütarlapsest sirgub naine tavaliselt esile kutsub. Nagu pealiskaudseist internetiotsinguistki näha, on E. Koogi teos olnud mingil ajal nii prestiižne, et selles tekstis esitatud hinnangud ja õpetused on mõjutanud nii mõnegi internetikommentaatori arusaamu "normaalsest" ja naisele sobivast käitumisviisist. Tõenäoliselt on paljud kõnealust raamatut lugenud naised tundnud end samamoodi, nagu eelnev internetikommentaator - "ebanormaalse" või "ebatäiuslikuna" - ning üritanud mitte käituda nii, nagu seda teevad hoiatuslugude antikangelannad.

\section{Tõe loomine ja kehtestamine}

Võib tunduda, et meditsiin ja humanitaarteaduslikud uurimisvahendid on täiesti sobitamatud. Seisukoht, mille kohaselt reaalteaduslikud ja meditsiinialased tekstid oleksid tunduvalt objektiivsemad või reaalsust kuidagi vahetumalt peegeldavad võrreldes mõningate muude tekstidega, on aga kindlasti illusoorne. Tänapäeval on ka folkloristid ja feministlikud uurijad analüüsinud näiteks haiguslugusid ning nendes sisalduvat retoorikat ja kujundeid, samuti muid näiliselt objektiivseid meditsiiniga seotud tekste (vt nt Ritchie 1993; Young 1993).

Et didaktiline kirjandus on tugevalt seotud folkloorsete žanridega, pole mingi uudis. Nii euroopalikes kui ka idamaistes kultuurides on tavaline, et

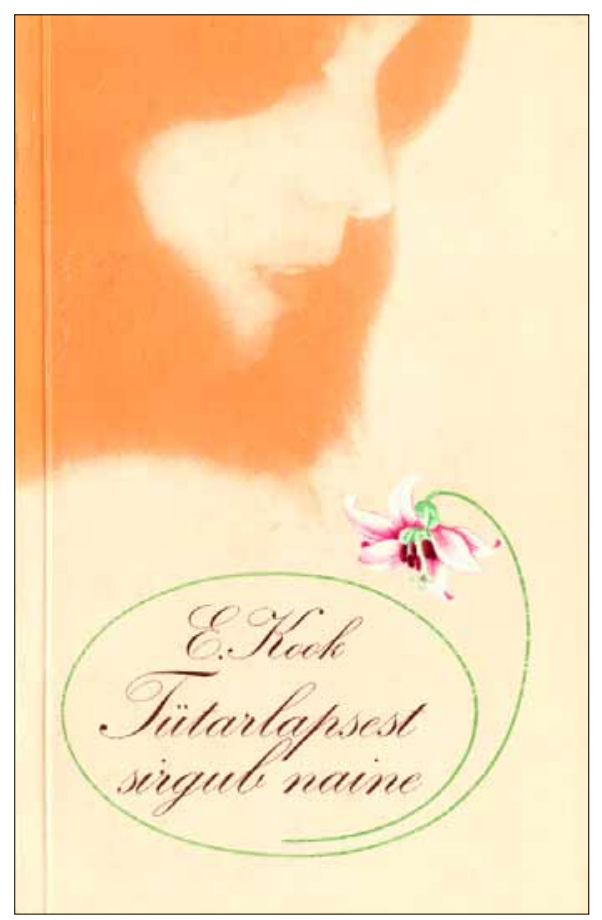


noortele suunatud tekstid sisaldavad valmilaadseid, mingi hoiatuse või moraaliga lõppevaid õpetlikke narratiive, samuti on tuntud näiteks vanasõnade rohke kasutamine didaktilises kontekstis. Didaktilised jutud ja valmid esitavad sageli teatud negatiivse pildi või loo, mille eesmärgiks on hoiatada ja näidata teatud valikute hukatuslikkust (Bausinger 1981: 615, 616).

Folkloristi tähelepanu võiksid köita E. Koogi raamatus Tütarlapsest sirgub naine 47 lühikest näitelugu, millest igaüks illustreerib mõnda hukkamõistu väärivat tegu või väära käitumismudelit. Lood on esitatud kursiivkirjas ja paigutatud näidetena samalaadset teemat käsitlevasse peatükki. Kõik lood, mida raamatus esitatakse, on väidetavalt tõestisündinud, need on "mõned üksikud näited" E. Koogi arstipraksisest ja eraelust ning nende publitseerimise eesmärgiks on kummutada väärarvamusi ja näidata nende hukatuslikkust. Autor ütleb raamatu sissejuhatuses:

Kogu see väärate teadmiste hulk, millega ma oma töös olen kokku puutunud, viis mind mõttele kirjutada tütarlastele raamat, mis aitaks elus õigemini orienteeruda (Kook 1986: 5).

Niisiis on nende lugude esitamise põhjused moraali-, tervise- ja hügieeniõpetuslikud. Lugude eesmärgiks on kindlustada antud ühiskonnas ka ametlikult tunnustatud arusaamu käitumisest, naise kehast ja kommetest.

Kogu E. Koogi tekst on illustreeritud rohkete näidetejuttudega ja õpetlikke lugusid tuleb ette ka mujal kui kursiivkirjas lõikudes. 47 kursiivkirjas lugu on aga kenasti välja arendatud ja tervikliku ülesehitusega. Neis on teatud vormelid ja struktuurid, mis korduvad loost loosse. Narratiive esitatakse tõestisündinutena, mõned neist oleksid justkui kogenud ja hea jutustamisvõimega meediku poolt rahvapärasel ja emotsionaalsel viisil ümber jutustatud haiguslood, mõned aga kui lihtsad kuulujutud või klatš. Lugude rohkus ja detailide värvikus tekitab kahtlusi, kas tegemist on tõepoolest polikliiniku naistearsti isiklike kogemustega. Kuidas sai naistearst teada, et sääreluu murdnud patsiendil oli menstruatsioon või kuidas ta teadis, milliseid dialooge peavad imikute vihased isad ja emad koduseinte vahel? Need ja paljud muud narratiivides sisalduvad värvikad detailid võivad ka pealiskaudsel analüüsil tunduda ülimalt kahtlastena ja viidata mõnele esteetilisele või kunstikavatsuslikule põhjusele, mille tõukel narratiiv on konstrueeritud.

Et rõhutada lugude tõepära, kasutab E. Kook mitmeid retoorilisi võtteid, mille ülesandeks on veenda lugejat, et kõik kirjutatu vastab tõele ja on justkui kontrollitav. Lugejale esitatakse enamasti viide loo toimumise kohale ja ajale, lugude protagonisti kohta on antud vanus või vähemasti viide tema staatusele (koolitüdruk, üliõpilane, noor ema jne). 
Ta toodi haiglasse kell 5.30 hommikul pärast pulmi. Ta oli blond 21aastane naine, kes oma pehmete, tüsedusele kalduvate vormidega meenutas kerkinud saiapätsikest (Kook 1986: 3).

Jaanuaris 1972. a. toodi haigla vastuvõtutuppa 22-aastane nägusalt riides ja kena naine (Kook 1986: 16).

Konsultatsioonile naistenõuandlasse pöördus 32-aastane naine, kes oli olnud 10 aastat abielus ja kellel oli 2 last (3-aastane poeg ja 7aastane tütar) (Kook 1986: 25).

Õhtul kell 22 toodi haiglasse 20-aastane naine üliraskes, teadvusetus seisundis. Kehatemperatuur oli $40^{\circ}$, pulsisagedus 130 lööki minutis, nahk kahvatu (Kook 1986: 25).

Nagu näha esitatud näidetest, on E. Koogi kirjeldused rõhutatult täpsed. Lugude alguses viidatakse sündmuste toimumiskohale (haigla, polikliinik, sünnitusmaja, nõuandla, kool, teismelise sünnipäevapidu jne), tekstides on rohkelt numbreid, esitatud on väga täpseid sündmuste toimumise aegu ja teatud laadi infot lugude peategelaste kohta. Inimeste kirjeldused on detailsed ja neis on sageli mingi meeldejääv, jutustaja antud võrdlus või väga subjektiivne hinnang. See oleks justkui vajalik näitamaks, nagu oleks jutustaja olnud kõigi nende õpetlike lugude pealtnägija ja tunnistaja.

Näiteks pulmaööl sünnitusmajja viidud pruut meenutab oma pehmete, tüsedusele kalduvate vormidega [---] kerkinud saiapätsikest, tripperisse nakatunud 10. klassi neiu on ükskõikse ja igavleva ilmega, sääreluu murdnud ja menstruatsioonisidemeta naine on nägusalt riides ja kena jne. Sageli kannavad sellised värvikad ja meeldejäävad kirjeldused ilmset kunstikavatsuslikku eesmärki: kui teksti alguses öeldakse naise kohta nägusalt riides ja kena, siis on selge, et jutu lõpus paljastub mingi räpane ja ootamatu puänt. Lood ongi tihti puänteeritud, lõpuks võidakse esitada selgesõnaline moraal:

Naine, kes pü̈̈dis ise rasedust katkestada, teha kriminaalset aborti, maksis selle eest oma eluga (Kook 1986: 32).

Esimestel eluaastatel jäi laps ilma sellest, mida ta kõige enam vajas oma vanemate hoolitsusest, tähelepanust ja hellusest. Selle tagajärjel kasvas üles pahur ja närviline laps, kellel puudus õige kiindumus vanematesse (Kook 1986: 52).

Vaesest sünnipäevalapsest oli südamest kahju, kuid kes käskis selliseid intiimesemeid lapsele kättesaadavasse kohta jätta! (Kook 1986: 18). 
Et lood oleksid mõjuvamad, on neis sageli sees tugevad vastandused. Ühelt poolt vastanduvad jumalikult kõikenägeva vaatepunktiga jutustaja ja protagonistid, teisalt on asetatud opositsioonipaaridena ka väär tegevus ja moraal selle kohta.

\section{Tütarlapsest sirgub naine kui folkloorikogumik}

Tütarlapsest sirgub naine on väga laia levikuga tütarlastele mõeldud väljaanne, milles avaldatud narratiivid on meeles paljudel seda jutukogumikku lugenutel. 1970.-1980. aastatel puberteediealiste eesti tütarlaste teadvuses on tõenäoliselt nii mõnigi nendest 47 näitejutu süžeest, aga võib-olla ka mõni konservatiivne tarkus naise keha või hügieeni kohta.

Meditsiinilised tõed on ajas suhteliselt muutuvad. Ka 20. sajandi jooksul on mitmedki arusaamad naisekehast ja hügieenist teisenenud. Tütarlapsest naiseks saamise teema on väga kultuurisidus ja peegeldab tundlikult antud kultuuris valitsevaid sooideoloogiaid ja tabusid. Isegi nendest teksti osadest, mida E. Kook on esitanud tõsiteaduslike ja meditsiinialastena, võib leida konstruktsioone ja arusaamu, mida tänapäeval peetakse pigem käibetõdede või folkloori hulka kuuluvaks. Kui võrrelda E. Koogi teost tema eellasega Tütarlapsest naiseks (vene keele vahendusel tšehhi keelest tõlgitud teose eestikeelne esmatrükk ilmus aastal 1962), võib selgelt näha, kui ideoloogilised, konstrueeritud ja muutlikud on noortele naistele suunatud meditsiinilised tõed (vt Peter \& Šebek \& Hynie 1964). E. Koogi teos on võrreldes oma eelkäijaga kahtlemata suhteliselt liberaalne. Kui 1962. aasta väljaandes peetakse näiteks menstruatsiooniaegset sportimist ja isegi tantsimist ebasoovitavaks, siis E. Koogi ajal (16 aastat hiljem) keelatakse sel ajal tegelda vaid teatud spordialadega.

Samuti nagu sport, suurendab ka tantsimine suguelundite täitumist verega ja on seepärast menstruatsiooni ajal kahjulik (Peter \& Šebek \& Hynie 1962: 38).

Menstruatsiooni ajal on keelatud tegelda selliste spordialadega nagu jalgrattasõit, aerutamine, ratsutamine ja ujumine (Kook 1986: 20).

Tütarlapsest sirgub naine representeerib antud kultuuris levinud norme ja tabusid. Kuigi ollakse rõhutatult seotud teadusliku diskursusega, on paljud sellistes tekstides edasi antavad õpetused seotud pigem tabude, kommete ja valitsevate sooideoloogiate kui meditsiiniga. Näiteks taastoodab E. Koogi teos tava pidada menstruatsiooni ja sellega seotud hügieenilisi abivahendeid 
eriliselt varjamisväärseks ning stigmatiseerib sellega seoses menstrueerivaid naisi.

Kord viibisin 15-aastase neiu sünnipäeval. Külalisi oli ligi kakskümmend: naisi ja mehi, vanemaid ja nooremaid. Ainuke laps oli sünnipäevalapse 7-aastane õde. Tal oli igav ja ta pü̈̈dis endale kõikjal tegevust leida. Siis järsku ilmus ta seltskonna keskele, keerutades sõrmede vahel puhast menstruatsioonisidet. "Kuule," küsis ta õelt, "kas ma võiksin selle oma nukumadratsiks võtta? Sul jäi neid sinna kappi veel küllalt." Kommentaare pole ilmselt vaja. Vaesest sünnipäevalapsest oli südamest kahju, kuid kes käskis selliseid intiimesemeid lapsele kättesaadavasse kohta jätta! (Kook 1986: 18)

Samamoodi demonstreerib E. Koogi teos sel ajal levinud tabusid seoses rasestumisvastaste vahenditega. Olles küll õpiku funktsiooniga raamat, ei leia autor ometi võimalust õpetada rasestumisvastaseid vahendeid kasutama. Ainus, millest peetakse sobilikuks ka lähemalt rääkida, on rasedusest hoidumise füsioloogiline meetod. Rasedusest hoidumist on käsitatud patoloogilisena. Selleks, et rasestumisvastaseid vahendeid kasutada, peaks naine esmalt pöörduma arsti poole. Muidugi peegeldab selline valik tõenäoliselt ka antud hetke kaubandust ning hügieenitarvete ja muude elementaarsete vahendite defitsiiti.

Naine, kes kavatseb rasedusest hoiduda, peab kõigepealt konsulteerima oma arstiga, tema abiga valima endale sobiva meetodi ning õppima käsitsema vastavaid vahendeid. Seepärast ei hakka ma üksikasjalikult peatuma rasestumisvastaste vahendite kasutamisviisidel. Põhjalikumalt käsitlen vaid füsioloogilist rasestumisest hoidumise meetodit. Esiteks sellepärast, et seda võivad kasutada kõik naised, sõltumata nende tervislikust seisundist. Teiseks sel põhjusel, et selle kohta on mulle loengutel kõige enam küsimusi esitatud (Kook 1986: 55).

Tütarlapsest sirgub naine õpetab antud ühiskonnas käibel olevaid ja normidele vastavaid käitumismudeleid ja käsitab patoloogilistena või esitab negatiivsete variantidena mitmeid alternatiivseid käitumismudeleid. Sünnitust peetakse nähtuseks, mis peab ilmtingimata toimuma haiglas. On äärmiselt ohtlik ja ebaõige, kui naine peaks haiglasse n-ö hilinema või sünnitab kusagil mujal. Samuti peetakse ainuõigeks ja normaalseks, kui last hoitakse sünnituse järel emast eraldi ja tuuakse ta juurde vaid toitmiseks. E. Koogi raamatus on omaette peatükk "Mida on vaja teada vanaemade probleemist", kus hoiatatakse alternatiivsete ja tema teosega mittekokkulangevate lastekasvatamise viiside eest. Vanaemal on sageli raske kuulata näljase lapselap- 
se nuttu ja söögiaegade rütmi rikutakse kergemini, ütleb E. Kook (1986: 115) sellise olukorra kohta, kus last ei söödeta kindlatel kellaaegadel.

Folkloristika traditsioonide kohaselt võiks jagada E. Koogi 47 narratiivi eksemplumiteks ehk hoiatusmuistenditeks, anekdootideks ehk naljanditeks ja argihirme kajastavateks linnajuttudeks. Hoiatusjuttudes räägitakse sellest, milliseid tagajärgi võib tuua väär käitumine. Sellised jutud lõpevad harilikult moraaliga, valesti käitujat karistatakse füüsiliselt või mõnel muul moel.

Kord sõitis haigla ukse ette liiniautobuss. Bussijuht talutas vastuvõtutuppa kahvatu ja oigava naise, kes kõndis väga vaevaliselt ning toetas mõlema käega kõhtu. Jutuajamisel selgus, et buss oli olnud sõitjaid väga täis. Üks väike poiss, kes pü̈̈dis endale reisijate vahel bussiukseni teed rajada, lõi naist kogemata kü̈̈narnukiga kõhtu. Naine tundis tugevat valu ja minestas. Bussijuht peatas sõiduki, enamik reisijaid väljus ning naine toodi haiglasse. Läbivaatusel selgus, et naisel oli menstruatsiooniside kinnitatud haaknõelaga pesu külge. Poisi kü̈̈narnukk oli selle lahti löönud (Kook 1986: 19).

Naljandi- või anekdoodilaadsed jutud põhinevad harilikult mingil koomilisel ütlusel, mis võib olla ühtlasi teksti puändiks. E. Koogi naljandilaadsetes tekstides on tegelasteks sageli lapsed ja koomilist situatsiooni tekitav ütlus võibki pärineda lapsesuust.

Emal on külas mõned endised kooliõed. Juuakse kohvi, aetakse juttu. 5-aastane Siiri mängib samas nukkudega. Jutt läheb ühisele tuttavale, kelle perekonnaelu pole eriti harmooniline. Ema sõnab: "Ma poleks kunagi uskunud, et Anne sellise täispuhutud ahviga hakkab ringi jooksma." Paar päeva hiljem kohtavad ema ja Siiri tänaval tädi Annet ja Siiri pärib: "Tädi Anne, palun näita mulle seda täispuhutavat ahvi!" Tädi Anne ei taipa, millisest ahvist tüdruk räägib, ning see selgitab sõbralikult: "Ema ütles, et sul on üks täispuhutud ahv, kellega sa ringi jooksed, kui onu Juhan komandeeringus on." Kodus sai Siiri emalt korralikult karistada, kuid mille eest, see jäi talle täiesti arusaamatuks. Karistus oli ebaõiglane ja kõigutas tugevasti tema usaldust ema vastu (Kook 1986: 125-126).

Peale selliste väljaarendatud naljajuttude leidub Ene Koogi kogumikus ka naljandilaadseid jutte, kus tuumaks on kellegi lausung, mis ongi jutu keskmeks ja puändiks. Sellistes nappides juttudes võivad saatelaused olla elliptilised ning juttudele pole lisatud isegi seletavat moraali. 
Noor perekond: isa, ema ja kolmekuune laps. Isa räägib emale: "Ma ei mõista, mis sinuga on juhtunud? Sa olid ise korralik ja meie kodu oli alati korras. Nüüd on kõik kohad lapse asju täis, ise pole sa enam ammu juuksuri juures käinud... Oled ju praegu kodus, aega on sul palju rohkem, aga enese ja kodu eest sa enam hoolt ei kanna (Kook 1986: 109).

Teatavasti on folkloorsete tekstide üks olemuslikke tunnuseid see, et need levivad ja varieeruvad. Kui lugeda nõukogudeaegseid raamatuid seksuaaltervishoiust, võib leida mitmeid motiive, mis teosest teosesse korduvad. Näiteks kui räägitakse suguhaigustest ja tuuakse mõni õpetlik hoiatuslugu, siis on selles loos tavaliselt üheks tegelaseks meremees. Sellise motiiviga narratiivi võib leida nii soome keelest tõlgitud ülipopulaarsest raamatust Avemeelselt abielust (Paloheimo \& Rouhunkoski \& Rutanen 1974: 182) kui ka E. Koogi teosest Tütarlapsest sirgub naine. Sirvides samal perioodil ilmunud populaarseid meditsiiniga seotud kirjutisi, võib neist leida mitmeid E. Koogi raamatus esinevaid jutustamisvõtteid või süžeid. Nii võivad naisteajakirjades ilmunud vastavasisulised kirjutised sisaldada E. Koogi loodud hoiatusjuttudele väga sarnase retoorikaga jutukesi.
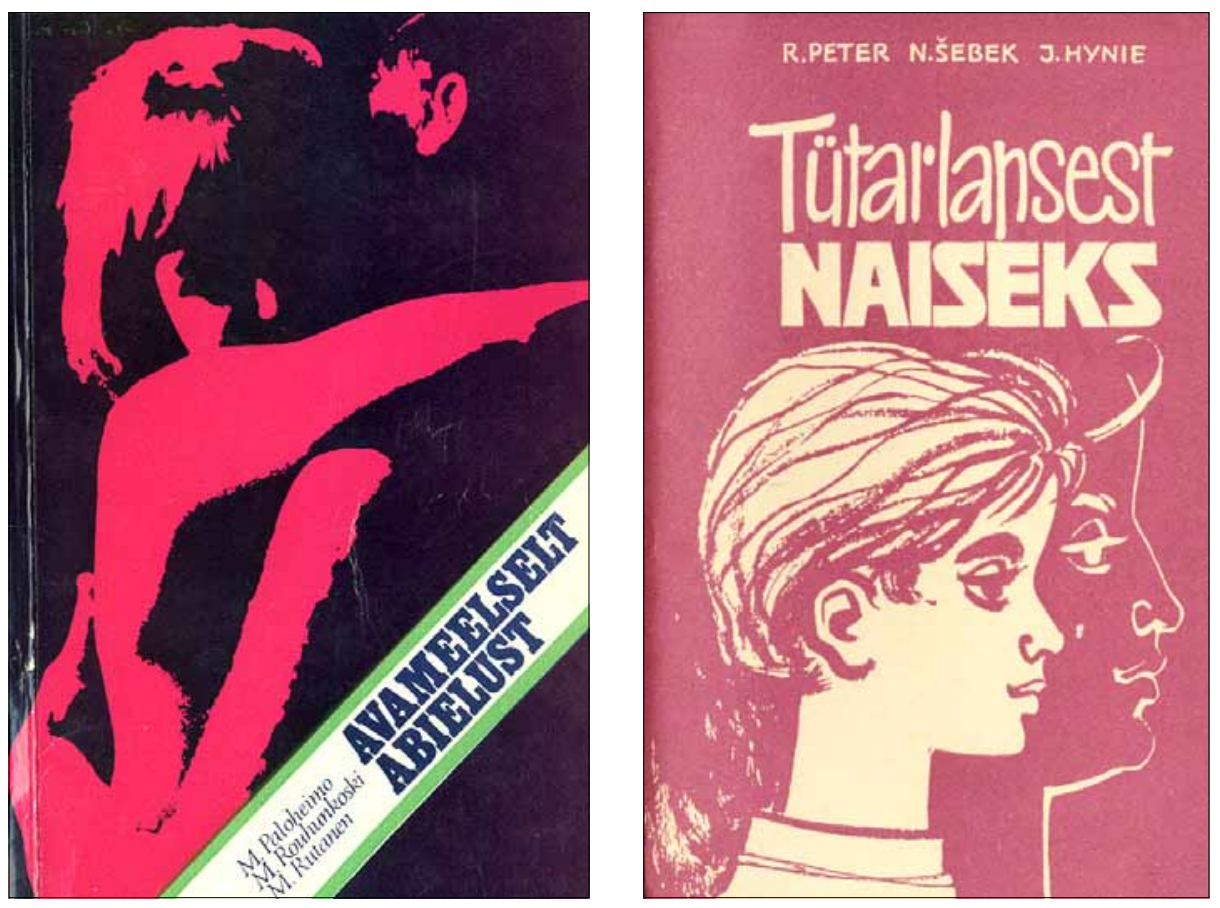
Arsti vastuvõtule tuli ema oma 15-aastase tütrega. Juba uksel avaldas ema kahtlust, et tütar on rase, kuna kuuriided olid lakanud. Tütre näolt peegeldus niisuguse kahtlustamise pärast sügav solvumine. Ema usaldamatus oli antud juhul täiesti põhjendamatu (Gross 1963).

Vastuvõtule tuli 17-aastane tütarlaps, Tallinna ühe tehnikumi õpilane. Ta päris, millise arsti poole peab pöörduma tõendi saamiseks, et ta pole olnud sugulises vahekorras. Tõendit vajas ta esitamiseks emale, kes juba teist aastat kahtlustas tütart intiimvahekorras ühe noormehega (Kook 1986: 121).

\section{Neutraalne ja vulgaarne keha ja keel}

E. Koogi tekstis esineb kaht liiki keha: üks on ülev ja neutraalne naisekeha oma anatoomilistes kirjeldustes, teine seevastu rõhutatult räpane, seksuaalne, halvasti koheldud, vigastatud või haige hoiatusjuttude keha. Esimest liiki keha on neutraalne või isegi sakraalne, see on justkui puhas aine, ideaaltüüp, mis pole seotud ühegi konkreetse naisega. Teist tüüpi keha meenutab bahtinlikku groteskset keha, see on vulgaarne keha, milles on avaused ja mis eritab lõhnu ja vedelikke, see on inetu ja ablas ning selle eest hoolitsetakse lohakalt.

Vene kirjandusteadlase ja filosoofi Mihhail Bahtini järgi iseloomustab groteskset keha see, et rõhutatud on neid kehapiirkondi, mis on avatud välismaailmale, st osi, mille kaudu maailm siseneb ja väljub kehast või mille kaudu keha ise endast väljub, et kohtuda maailmaga. See tähendab, et rõhk on keha avaustel ja kumerustel, erinevatel hargnemiskohtadel ja harudel: avatud suu, suguelundid, rinnad, fallos, kõht, nina (Bakhtin 1984: 26). Grotesksele kehale vastandub klassikaline keha, mis on M. Bahtini arvates modelleeritud kreeka kujude eeskujul ja millel pole avausi ega pilusid ning mis seetõttu ei erita ega võta ka midagi vastu.

N-ö klassikalist keha kirjeldatakse Tütarlapsest sirgub naises anatoomiast ja keha funktsioneerimisest rääkides suhteliselt neutraalsel toonil, keel on kujundlik ning võrdlused on kunstipärased ja positiivseid assotsiatsioone esile kutsuvad (puuviljad, pehmusele ja õrnusele viitav leksika).

Suguelundid on väga õrnad ja loodus on neid hästi kaitsnud. Nad asetsevad väikevaagnas. [---] Munasarjad on väikesed, umbes ploomisuurused elundid, mis asetsevad teine teisel pool emakat. Nad on ümbritsetud munajuhade narmalistest otstest. [---] Emakas on pirni- 
kujuline tihke lihaseline elund, mis paikneb väikevaagnas munasarjade ja munajuhade vahel (Kook 1986: 7-9).

E. Koogi kasutatud retoorika viitab sellele, et kirjeldatakse austuse ja imetlusega looduse imelist loomingut. Mitmel puhul loodus isikustatakse, rõhutades sellega n-ö klassikalise keha sakraalsust ja vooruslikkust:

Eelmisest peatükist lugesite, et loodus on teinud omalt poolt kõik võimaliku selleks, et kaitsta suguelundeid haiguste ja vigastuste eest (Kook 1986: 11).

Keha, mida kirjeldatakse, on rahulik, tugev ja väärikas - arhetüüp, millel pole märkigi mingist nõrkusest või isikust, kellele see peaks kuuluma. Hoiatuseks toodud haiguslugudes ilmneb aga hoopis teistsugune keha - see on vigastatud, eritistega määritud ja halvasti koheldud.

Jaanuaris 1972. a. toodi haigla vastuvõtutuppa 22-aastane nägusalt riides ja kena naine. Tänaval kukkudes oli ta murdnud parema säöreluu. Kui haiget lahti rõivastati, selgus, et tal oli menstruatsioon. Menstruatsioonisidet tal polnud, kuid tal oli seljas pikem öösärk, särgisabad olid jalge vahelt läbi tõmmatud ja vähemalt kolme päeva vanuse verega läbi imbunud. Kõvakstõmbunud veri oli isegi naha reitel katki hõorunud (Kook 1986: 16-17).

Selline groteskne keha toitub ja seedib, on seotud valude, piinlike eritiste ja ebameeldivustega, see käitub irratsionaalselt ja ootamatult. Groteskne keha pole juhitav ega kontrollitav, ta funktsioneerib sõltumata inimese tahtest.

19-aastane tütarlaps, kes keskkoolipäevil oli korduvalt põdenud maokatarri, pöördus polikliinikusse, kurtes endise haiguse ägenemist. Tal esines iiveldus ja oksendamine, mis söömisega otseselt seotud polnud. Jutuajamisest selgus, et mõned nädalad tagasi oli tütarlaps oma suhetes noormehega esmakordselt läinud sugulise kontaktini. Täielikku suguühet aga ei olnud toimunudki, sest tütarlast häiris tugev valu. Soovitasin siiski konsulteerida naistenõuandlas raseduse suhtes. Algul tütarlaps keeldus. Talle näis, et rasedus pole lihtsalt võimalik. Pärast ta siiski nõustus konsultatsiooniga ning selgus, et iiveldus ja oksendamine olid tõesti põhjustatud rasedusest (Kook 1986: 57).

Meditsiiniline kirjandus assotsieerub euroopalikus kultuuris aristokraatliku ja üleva diskursusega. M. Bahtini järgi on aristokraatlikul diskursusel kolm omadust: see seob osalised oma veenmiskunstiga, on distantseeritud ja ülev, 
samas ka tunnustatud ja autoriteetne ning selle keel on spetsiifiline ja hierarhiseeriv (Bakhtin 1981: 342). Aristokraatliku diskursuse osaks on ka aristokraatlik keel. Nii tajutakse euroopalikus kultuuritraditsioonis ladinakeelseid termineid puhta ja ülevana, need oleksid justkui vabad igasugusest vulgaarsusest ja jämedusest. Ladina keel oma püha ja religioosse keele staatusega oleks justkui vaba barbaarsetele keeltele omastest labasustest ja pärjatud rituaalse autoriteediga.

E. Kook seob oma teoses aristokraatliku ja madala diskursuse. Kõige labasemad ja eluga seotumad teksti osad on eraldatud ülevast tekstist ja paigutatud kursiivi. Pedagoogilisele või didaktilisele diskursusele iseloomulikult on stiil segatud ja adapteeritud, ülevate kirjelduste kõrval on ka lihtsaid seletusi ning ülevate asjade paremini mõistetavuse nimel on sisse toodud n-ö elulisi, labasemaid näiteid ja seletusi. Tütarlapsest sirgub naine on didaktiline raamat noortele naistele. Õpetlikud narratiivid, mis pärinevad väidetavalt elust, kuid meenutavad oma olemuselt väga folkloorseid tekste, kannavad selgelt ülesannet õpetada noortele naistele selgeks antud ühiskonnas kehtivad sooideoloogiad ja kehaga seotud tabud.

E. Koogi raamat on suurepärane näide sellest, kuidas populaarses didaktilises tekstis kohtuvad folkloor ja meditsiin. Traditsiooniline jutustamiskunst ja vanad jutužanrid ning tollel hetkel aktuaalsed ja tunnustatud meditsiinilised tõed naisekehast ja naisele sobilikust käitumisest saavad kokku Tütarlapsest sirgub naine värviliste kaante vahel. Üleva ja madala didaktilistel eesmärkidel ühendamine ning ladusate narratiivide konstrueerimine on kandnud kindlat eesmärki mõjutada lugejat. Millise ja kui sügava jälje on sellised didaktilised tekstid jätnud nende lugejatesse, on muidugi omaette teema, mis nõuaks põhjalikumat uurimist.

\section{Kirjandus}

Bakhtin, Mikhail 1981. The dialogic imagination: 4 essays. University of Texas Press slavic series 1. Austin: University of Texas Press.

Bakhtin, Mikhail 1984. Rabelais and his world. Bloomington: Indiana University Press.

Bausinger Hermann 1981. Didaktisches Erzählgut. Ranke, Kurt \& Bausinger, Hermann (koost \& toim). Enzuklopädie des Märchens: Handwörterbuch zur historischen und vergleichenden Erzählforschung 3. Berlin \& New York: Walter de Gruyter, lk 614624.

Delfi Naisteleht (http://woman.delfi.ee/ - 10. september 2006).

Gross, Kadri 1963. Emale tütrest. Nõukogude Naine 1, lk 14.

Kook, Ene 1978, 1979 \&1986. Tütarlapsest sirgub naine. Tallinn: Valgus. 
Ritchie, Susan 1993. A Body of Texts: The Fiction of Humanization in Medical Discourse. Young, Katharine Galloway (toim). Bodylore. Publications of the American Folklore Society: New Series. Knoxville: The University of Tennessee Press, lk 205-223.

Young, Katharine Galloway 1993. Still Life with Corpse: Management of the Grotesque Body in Medicine. Young, Katharine Galloway (toim). Bodylore. Publications of the American Folklore Society: New Series. Knoxville: The University of Tennessee Press, lk 111-133.

Paloheimo, Martti \& Rouhunkoski, Mauri \& Rutanen, Mirja 1974. Avameelselt abielust. Lühendatud väljaanne. Tallinn. Valgus.

Perekool: Eesti Ämmaemandate Ühingu Interneti väljaanne (http://www.perekool.ee/ - 10. september 2006).

Peter, Rudolf \& Šebek, Václav \& Hynie, Joséf 1964. Tütarlapsest naiseks. Tallinn: Eesti Riiklik Kirjastus.

\title{
Summary
}

\section{"A Girl Becomes a Woman" Cautionary Tales for Young Girls in Popular Medical Literature}

\author{
Andreas Kalkun
}

Key words: didactic literature, popular scientific medicinal literature, puberty, gender ideologies, health education in Estonian SSR, true experience stories

A Girl Becomes a Woman (Ene Kook 1978, 1979, 1986) was a widely available publication for young girls. A substantial number of the 47 stories within this book made a great impact on teenage girls in the 1970s and the teaching on women's bodies and hygiene was accepted as common knowledge. The text is illustrated by many stories and these stories actually appear throughout the book and not only in the passages specifically marked as such. In the book there are 47 well-formed tales with a perfectly balanced structure. The tales include certain formulas and structures which recur from story to story. According to the traditions of ethnology, the 47 narratives by Ene Kook can be categorised as exempla or cautionary tales, anecdotes and urban myths. Cautionary tales warn people about the consequences that wrong behaviour may have. These stories usually end with a moral note in which those who have behaved badly receive a just penalty, whether physical or otherwise. Anecdotes are usually based on some comic saying, which at the same time can function as the punch-line to the story. Beside well-developed anecdotes you can find other anecdote-like stories in the book where someone's utterance is the core and punch-line of the story. In these brief stories the sub-clauses may be elliptical and the stories do not contain a moral lesson.

A Girl Becomes a Woman is an educational book for young women, in which folklore and medicine meet. The teaching narratives found in the educational text, supposedly 
from true experience, in essence remind us of folklore texts, and their intended purpose is to teach young women the gender ideologies and taboos related to the human body in the given society. The traditional art of story-telling and old narratives and the established medical truths about female body and how women should behave meet between the covers of A Girl Becomes a Woman. The joining the "high" and "low" for educational purposes and constructing coherent narratives has been done with the intention of influencing the reader.

A Girl Becomes a Woman represents the norms and taboos of the society. Despite the academic inclination of the book much of the teaching has been delivered by means of taboos and traditions and gender ideologies rather than actual medical concepts. For example, the book supports the idea that menstruation and feminine sanitary products are considered to be shameful and by doing so stigmatises menstruating women.

Ene Kook's text refers to two types of body - one is an ideal and neutral female body in the anatomic descriptions and the other is an extremely dirty, sexual, badly cared for, injured, or sick body of the cautionary tales. The first type of body is neutral or even sacred; it is like a pure substance, an ideal type that does not refer to any real woman. The other type of body reminds us of the grotesque body á la Bakhtin, it is a vulgar body, which has orifices and which excretes smells and fluids, it is dirty, ugly and voracious and badly cared for.

While taking a closer look at Ene Kook's text, you may notice how this typical educational text establishes a certain type of power relations, presents its standpoints as unquestionable ones, pathologises natural behaviour or normal phenomena and contrasts scientific ("high") discourse with the popular ("low") one. Looking at the given book in the context of folklore texts and comparing the narratives found in the popular medical literature with folklore genres, a certain alienation effect will emerge. Through the comparison and alienation effect the similarity between the popular medical texts and traditional story telling genres can be observed. The deconstructed medical narratives will reveal their constructed structure and strong ties with the society or ideologies and the texts appear to be something more than just a handbook of hygiene and good behaviour for young girls. 